\title{
The Symbolism and Imagery in Housman's Poetry with special reference to "By Rue My Heart Is Ladden"
}

\author{
Dr Veena Ilame
}

Assistant Professor, Department of English Literature, A.G. College Nagpur-440013, Maharashtra, India

\begin{abstract}
It is the often case that, in the era of modernization, a rich and extensive literature has been written since evolving in the form of time. Symbolism plays a role, an important condition in all areas of human life that has been respected since the origin of the Bible and other scriptures. Orthodox scriptures, verdicts and Buddhas pave the way for the true spirit of unshakable natural science in the eastern world. Nature has a strong wilderness in ordinary human life. This combines all the essential fulfilment of life. Every strange metaphor forms a regime from living memories. Therefore, this effort examines the habitual participation of loving souls in nature with every true aspect of modernization to gradually regulate the time torn apart.
\end{abstract}

Keywords-Bible, era, extensive, literature, modernization, Nature, symbolism, souls.

\section{INTRODUCTION}

The novice Latin professor, a scholar, and a famous poet left eternity on 30 April 1936. Men with a love for nature were born on 26 March 1859. When someone found him as a great poet of the Age, famous for his poetry cycle - A Shropshire Lad. He is a prominent classicalist at his age. He founded the publishing of his reputation as a private scholar and for the strength of his writing was appointed as Professor of Latin at University College, London and then Cambridge. His writings and editions are still considered authoritative. He is a scholar of openness. He loves nature. and the findings of a true vacation in classical studies made him not speak about his poetry in public until 1933 when he gave a lecture on "Names and Nature of Poetry". He died at the age of 77, at Cambridge, where he took up the position of permanent lecturer.

The approach is interesting and revealing, the most beautiful of trees, cherries now have layers of thematic and formal structures that make it responsive to many different readings. For example, this can be seen from the [postcolonial] point of view of eco-criticism in this article, this shows that in animal and plant relations, politics and power are like the Bible, reciprocal relations between nature and culture, etc. Therefore, the purpose of this article is to study the manifestations, branches, and nuances of this cross-reference. As in the dictionary and glossary, cross-references show that two terms refer to one ISSN: 2456-7620

https://dx.doi.org/10.22161/ijels.54.18 another and are understood comparatively. In this article, he shows how nature and culture, which are built into forest characterization, are depicted in a standpoint that is unified and distorted.

Alfred Edward Housman, a classical scholar and poet who was recognized for the popularity of his work "A Shropshire Lad". The poems are also in the form of Lyrical, concise, intelligent, and funny, the poems describe the disappointment of young people in the English countryside. These poems are known for their beauty, simplicity, and distinctive description. This is very attractive to Victorian and Edwardian tastes. The 20th era was strongly associated with Shropshire through the arrangement of the song. Housman specialized in Latin poetry even though his initial work and responsibilities as a professor included Latin and Greek. When asked later why he stopped writing about the Greek verse, he replied, "I find that I cannot achieve excellence in both." [17] In 1911 he took Kennedy's professorship in Latin at Trinity College, Cambridge. With Rue My Heart is Laden

By A.E. Housman

Regretfully my heart is laden

For the gold friends that I have, For many young rose girls And many lightfoot youths.

With tributaries too broad to jump 


\section{Barefoot boys lying down;}

Rose-lipt girls are sleeping In fields where roses fade.

A Shropshire Lad is a collection of very simple and effective poems from Alfred Edward Housman. It has a deep feeling of loss and bitter nostalgia. It is a difficult lesson for young people to learn because it is the nature of young people to feel emotions that they will live forever, even though their rational thoughts say otherwise. But inevitably, we all come to "the river is too wide to jump," and is placed in "the fields where roses fade." Alfred Edward Housman's big prize is about his very simple poetry and expressing impermanence in life, inconsistent with the nature of things.

Much of Housman's poetry such as "Loveliest of Trees" is reminiscent of Edward Fitzgerald's translation of Rubaiyat from Omar Khayyam. Khayyam deplored the brevity of human life in its many rubaiyat and emphasized full enjoyment of every moment of our earthly existence in the Epicurean way. Housman's attitude towards human life is more Cyrenaic than Epicurean. However, in many poems, the person recognizes mortality and decay and this recognition leads to acceptance of death rather than more meaningful participation in life activities. for example, characterizing life as a process of changing cycles that ends only in death. The speaker in the poem asked: "What is the point of getting up and getting up? / Awaken a thousand people in the morning, but finally, he lies down ... '". And the lines of the last verse strengthen the absolute process by this analogy: "The sun always moves west; / The way a worker goes / Will lead one house to rest ... "'In the end, the persona adds acceptance of death as the end of the cycle:" And that will be the best. "'

"The Most Beautiful Tree", seems to be the simplest poetic greeting. It opens with images of nature that seem to suggest the beauty of life at its peak: 36 of the most beautiful trees, cherry blossoms now hanging along the branches, and standing around the Wearing white forest trip to Eastertide, But the picture has an ironic effect on the observer; it reminded him of his mortality: Now, from my third year ten and ten, Twenty will not come again, and taking from seventy springs the score only makes me fifty more. The reaction is more complicated by the last verse because instead of being pessimistic when facing death, the speaker decides to involve himself in the beauty of the world even though it will be "hung with snow," coloured by knowledge of death: And because to see rife things. small room. The statement of the surface of the poem is simple: life is beautiful but short; and because it is short, we must enjoy it now. But Housman's treatment of the theme is not as simple as it seems. The poem looks simple because of its pastoral mode. This situation was felt through the eyes of the Shropshire youth himself, a modern pastoral figure. Cherries, the "most beautiful tree," are, in the true sense, the tree of knowledge in the poem, and the changes in the images associated with it show the transition from innocence to knowledge.

After being introduced in lines 1 and 2, the cherry tree is mentioned three times. Inline 4 it is said to be "wearing white for Eastertide," on line 9 it is called something "blooming," and in the last row the poem is said to be "hung with snow." What these three images suggest has become a point of debate for critics. Winifred Lynskey has said that images of snow accompanied by winter advice and death, only continued the relationship with the death that was introduced "Eastertide" in the first stanza; Werner argues that snow, in its poetic sense, is nothing more than "the mass of white petals," and Easter associations with death are "mere deviations because if Easter has meaning, it is the resurrection and eternal life." Easter is indeed a poetic symbol, traditionally associated with spring and rebirth, not winter and death. It is also true that phrases like "hung with snow," cannot be separated from the meaning attached to it through traditional associations. The expression "wear white for Eastertide," and "hang with snow," both clearly illustrate the white of cherry blossoms. But the images cannot be limited to colour associations, and snow brings with it winter and death just as Easter brings with it the idea of spring and rebirth. What has been ignored is that the "snow" from the last line obtained the full symbolic meaning of the structure of the poem. The image pattern develops from spring ("wear white for Eastertide") to summer ("blooming objects") to winter ("hung with snow"); or if someone prefers, from rebirth to growth, to death.

It is a clear increase in the knowledge of young people who observe that the "most beautiful" aspects of nature are the touches of melancholy because they reveal a world of damage and death. ("Reveille"), continuing the theme set in the "Loveliest of Trees". The title of the poem shows the subject and its central metaphor. This is a call to action in the face of death. This poem develops its theme through the metaphor of the sun's journey from dawn to dusk. The poem, as Keith Jebb stated, "captures the tone of temptation, the desire for broader horizons." Repetition of phrases such as "boys" and "wake up" show an urgent tone for young men who are fast asleep at dawn:

Some Housman critics have misinterpreted the views contained in A Shropshire Lad because they ignored this line of development. Hugh Molson, for example, stated that Housman considered human life "an improper trial which had no useful purpose other than from where 
humans obtained their final deliverance after death." $\wedge$ Stephen Spender found that "shooting, suicide, shooting, war, Hemlock" from Housman's poems expressed his feelings about "the misery of life ..." Edmund Wilson wrote that in Housman's poem "we only find the realization of the smallness of mankind ... "of his own fundamental mistakes for himself, his inescapable sadness." But we have seen that "Reveille" and the "Loveliest of Trees" encourage us to have meaningful existence even though they make us both aware of near death. Housman's poetry revolves from one standard to another.

Housman's own life was also marked by the same type of search for eternity reflected in his poetry. On October 3, 1892, he delivered a traditional introductory lecture to open the academic year before the Faculty of Arts and Law and Science at University College, London. He talks about learning values and knowledge, and one passage is very important because it shows that his choice of scientific life might be related to the theme that characterizes his poetry. He has stated; Intellectual pleasure is less well known than sensual pleasure or affection pleasure; and therefore, especially in the winter, the pursuit of knowledge is likely enough to be ignored and a little valued compared to other pursuits that offer far more powerful attractions.

Here we find the connection between Housman's scholarship and his poetry. Both represent a search for immortality in a world that can change. The unique quality of learning for Housman is that it is not subject to "wear of time." It became clear from the lecture that how strong the change process affected Housman's thinking and writing. The lecture was delivered less than three years before spring 1895 when many A Shropshire Lad poem was written. The search for immortality, which is part of the argument for the supremacy of intellectual pleasure for sensual pleasures in Housman's scientific activities, became a turning point in Housman's poetry. It is in this context that his attention to death at A Shropshire Lad must be seen. the introduction of the paper should explain the nature of the problem, previous work, purpose, and the contribution of the paper. The contents of each section may be provided to understand easily about the paper.

\section{LINEAR DIRECTION AND ALLEGORY}

Lines such as cerah sunny hills, bright valleys of poetry "hills and the Nile" evoke the image of nature. Housman Poetry assesses the power of nature with its positive attitude. The poem shows a romantic view of the amazing power of nature to lift and lift the soul. In this way, positive nature motives reinforce key themes such as life and regeneration, flares are also strong symbols of hope and life. This positive connotation is reinforced through the religious and patriotic nuances of the poem. Flares also represent individual inheritance. This flare burns on the road to heaven. In this way, the flare is a symbol of one's strength, potential, dreams, and desires. These aspects can transcend mortal existence, as they move from person to eternity. Modern humans are spiritually hollow and barren, they are like robots that follow previously assigned tasks. He got up early, changed his clothes, had breakfast, went to the office, had lunch, returned to his house, spent time with his family, had dinner, slept, and the following morning followed the same routine.

Modern people are a human-land dweller, although he has made progress in materialistic science and culture, he has no values, he is spiritually dead. He only has one trading eye, his spiritual eyes are closed, so he is spiritually blind. Some of the reasons for the destruction of modern humans are ignorance and gambling, making false love and religious disobedience. He is limited to his routine work and is powerless to act based on religious doctrine or moral values. Religion is the only way to get liberation, mortal man, he can be eternal like Christ by adopting God's message. Poetry "With Rue My Heart is Laden" digs the graves of past events and shows us eternal activity, ignorance, and spiritual infertility and this is the great skill of poets. Through this symbolic and figurative analysis of poetry, researchers will try to show a picture of emptiness and infertility today.

Alfred Edward Housman stands as a great poet of the twentieth century. He is considered a rebel poet, who discusses village life, his sterility, the busy activities of the eternal attitude of Laden village and the loss of belief in religious traditions, spiritual sterility, and arrogance and so on. It is said that a poet who is great at writing about him writing his age, we find the same quality in Housman's poetry. He uses traditional symbols and personal symbols in his poetry. $\mathrm{He}$ is an obscure symbolist; an ordinary reader can never easily understand the symbol. As far as the figures of speech are concerned, he uses Shakespeare and Miltonic as well as references to Dante and Lord Buddha in his artwork. He also uses certain Christian myths and at the same time, he introduces us to Greek mythology. "With Rue My Heart saden" is extraordinary poetry.

The basic voice of this conjecture is that Houseman's "excitement" implies an emotional state caused by personal unrest and any attempt to arrive at the cause of the riots. A further implication is that knowledge of causes of joy can express the symbolic attitude of the motivation behind Houseman's writing of A Shropshire Lad and further strengthen their position which insists on interpreting 
Houseman's poetry biography. But Houseman's unpublished letter indicates that the allegations of these scholars were the result of a misinterpretation of the word joy as Houseman used it. In a letter to Paul V. Love, an American, dated February 14, 1927, said Houseman, the joy is what is commonly called poetic inspiration. This clarification dismissed the idea that words from the preface disguised some personal revelations because excitement shows a separate emotional state from the creation of poetry while inspiration does not.

Elsewhere Houseman also tried to reject the notion that his poetry was a result of personal tragedy or crisis. In response to questions, while A Shropshire Lad was the result of a crisis of pessimism, he replied that he had never experienced a crisis like that. He added, "... I didn't start writing poetry seriously until the real emotional part of my life was finished ..." Besides, Wilfrid Scawen Blunt wrote In My Diaries about conversations with Housman where he asked the poet whether every episode in his life suggested that the letter contained only one sentence quoted above the terrible character of his poem. Houseman assured that Joe was not.

He once lived as a boy in Worcestershire, not in Shropshire, despite the views of the Shropshire Hills, and there was nothing terrible to note. Housman's explanation of his remarks in the introduction to Last Poems, which has not been discovered to date, makes it increasingly difficult for scholars to find personal events which sparked a very creative period in the early months of 1895 when most of Shropshire Lad's lyrics were written. But about preventing a purely biographical approach to poetry, some things may have helped prepare the way for critical evaluation of much-needed poetry based on his abilities, regardless of his disclosure of poets.

\section{CONCLUSION}

It can be concluded that Housman's poetry is an important part of his biography. To understand his biography, one can read his poetry, one of which is important among them is A Shropshire Lad. This is a series of self-expressing lyrics enough to understand Housman's work. One of the objectives of this study was to show Housman's work. This is not to deny that there is a personal element in poetry, but to deny that knowledge of personal elements is sufficient or even necessary to explain poetry.

\section{REFERENCES}

[1] Salinger, Herman. 'Housman'.288-290's the last poem
[2] Sitwell, Edith. 'Three Era of Modern Poetry', In Trio by Osbert, Edith, and Sacheverell Sitwell. London: Macmillan. 1938,97-139.

[3] Sparrow, John. Echoes in A.E Poetry. Housman, 'Nineteenth Century, 243-256.

[4] G.A. Simcox, Mr T. Burns Haber and Housman's Gate of Hell (1954), 437-442... 